DOI: 10.1515/jolace-2015-0015

\title{
In the postmodern mirror: intertextuality in Angels and Insects by Antonia Susan Byatt
}

\author{
Agata Buda \\ Kazimierz Pułaski University of Technology and Humanities in Radom, Poland \\ abuda@uthrad.pl
}

\begin{abstract}
The aim of the paper is to analyse the novel Angels and Insects by Antonia Susan Byatt in terms of intertextual references. The author's assumptions are based on the categorisation by Ryszard Nycz, who distinguishes three major types of intertexts: text versus text, text versus literary genre and text versus mimesis. Byatt uses intertextuality mainly to comment on the role of nature in the world, as well as to enhance the importance of human relationship with nature. Moreover, the writer moves towards literary criticism, discussing poems by famous artists, such as Alfred Tennyson or John Milton. In this way, the novel by Byatt is also an example of metafiction. All the narration techniques used by the English writer make the novel a typically postmodern work of art.
\end{abstract}

\section{Keywords}

intertextuality, postmodernism, metafiction

\section{Introduction}

Antonia Susan Byatt is a contemporary postmodern writer whose works can be distinguished by specific kinds of narration. They contain numerous references to English literature presented through the use of intertextual technique. Byatt utilises the knowledge of different literary époques, among which Victorianism is most frequently present. Her work Angels and Insects contains two stories: "Morpho Eugenia" and "Conjugal Angel". They are both revisions of the nineteenth-century world of science and literature and exploit numerous literary references.

The notion of intertextuality itself is not easy to be defined. As Hejmej claims (2012, p. 13), there exist diametrically different individual opinions and definitions of intertextual references, which is why it seems impossible to agree on one clear view. The reason for this is that scholars analyse intertextuality from various perspectives based on incommensurable assumptions. To present the complexity of intertextual references in a concise way in Byatt's work, I will mainly concentrate on the theory put forward by Nycz, who distinguishes three types of intertextual references:

1. Text vs. text

2. Text vs. literary genre

3. Text vs. reality $(1995, \text { p. } 65)^{1}$

\footnotetext{
${ }^{1}$ The division by Nycz can be compared to one of the five types of transtextuality distinguished by Genette. Genette divides all the text relations into: intertextuality (quotation, plagiarism, allusion), paratextuality (title, preface etc.), metatextuality (commentary on another text), architextuality (defining the type of writing: essays, poem etc.) and hypertextuality (usually a transformation of another text) (2014, p. 7-13). According to Genette's categorisation, Byatt uses mainly intertextuality (quotation) and metatextuality (commenting other texts focused on literary criticism).
} 


\section{Intertextual references}

The first of the stories "Morpho Eugenia" exploits intertextual references of the types 'text versus text', as well as 'text versus literary genre'. It describes the life of William Adamson, a scientist doing research on insects in Amazonian forests. He goes back to England and makes friends with the Alabaster family. Later on, he marries Eugenia Alabaster and faces various marital difficulties. His story is interwoven with a precise observation of the life of ants, compared to human existence. The narrator, by referring to different literary works, attempts to show the place of the human race in nature. A quotation from the Bible presenting the power of animals draws the reader's attention to the idea that people are part of nature rather than the ruling race:

There be four things which are little upon the earth, but they are exceeding wise:

The ants are a people not strong, yet they prepare their meal in the summer;

The conies are but a feeble folk, yet make they their houses in the rocks;

The locusts have no king, yet go they fort hall of them by bands;

The spider taketh hold with her hands, and is in kings' palaces.

Proverbs 30, 24-8

(Byatt, 1992, p. 15)

The world of nature should not be ignored by humans. This is the conclusion that is drawn by William Adamson during his observations. Animals, especially ants, possess qualities that evoke respect or even fear in people. The structure of ants' society together with its buildings, work organisation and family duties, becomes an object of admiration for William and his companions. Miss Mead, William's colleague, while observing an anthill of dangerous red ants, compares it to Milton's Pandemonium, quoting at the same time the vast passage from Paradise Lost (Byatt, 1992, p. 79). Milton's famous work also becomes the way to express William's feelings of melancholy and longing. The scholar compares the passage describing expulsion from Paradise to his journey back home from the Amazonian forests (1992, p. 31). William frequently misses his stay in Amazonia and the quiet life in natural surroundings. On the other hand, he admits to himself that during hot weather in the tropical Amazonian places he used to miss the English spring and recall the poem by Robert Browning "Home Thoughts from Abroad":

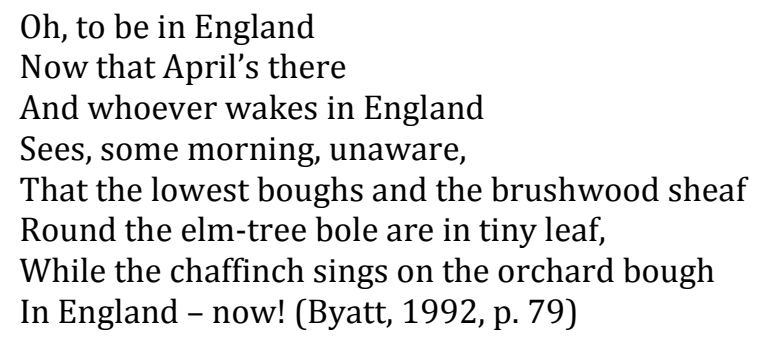

The 'text versus text' relations underline nature as the crucial element of human life. This is mainly an appreciation of the power of nature together with admiration and respect. The same subject appears in 'the text versus literary genre' intertextual relations. Byatt exploits legends, fairy tales and scientific books in order to enhance the plot of her two stories. Quoting other literary works is a way of using a prototype of a work belonging to the particular literary genre (Markiewicz, 1989, p. 208).

One of the legends is a revision of the story of Cupid and Psyche, told by Miss Mead to a group of young girls. In the story ants help Psyche to sort the amounts of different seeds. The task was imposed on Psyche by Venus, the Goddess of Beauty. According to William and Matty Crompton, the story's aim is to present these useful insects as helpful, hard-working and clever animals and compare them to 
humans (1992, p. 43-44). A similar question is raised in the tale by Matty Compton read by William one day in bed. The story entitled "Things Are Not What They Seem", presents a man named Seth who travelled around the world and took care of different animals. While in danger, he is directed by an ant to leave some winding tunnels. The ant is willing to help the man, saying: '(...) I can do you a good turn, for you saved my life (...)' 'I can get in and out of here. If I can, you can. Please follow me' (Byatt, 1992, 125-126).

The relationship between the ant and the man is evidence of the mutual coexistence of the human world and that of animals. It shows the need for a balanced interrelationship. Cherishing nature is indispensable, since animals and humans have numerous things in common. This subject is described in another work included by the narrator in the main story. This is William Adamson's book on insects, whose passages are frequently quoted in "Morpho Eugenia". The information about the book is given in a precise way; it is not limited to the text itself but also provides the reader with details of paratextual nature: ${ }^{2}$

The book was put together in a provisional way during the Winter of 1862 . Its final title was to be THE SWARMING CITY

A Natural History of a Woodland Society,

its polity, its economy, its arms and defences, its origin, expansion and decline. (Byatt, 1992, p. 108)

In his book, William Adamson emphasises the ants' instinct and compares it to human intelligence: "I have seen a crew of a dozen ants manoeuvre a stem as tall, to them, as a tree to us, with about as many plausible false starts as a similar crew of schoolboys might make, before finding which end to insert at which angle" (Byatt, 1992, p. 110).

The subtitles themselves are organized in such a way that they seem to refer to the structure of the human world; the words like society, economy and arms, prove the close link between animal and human patterns of life. William's book often provokes the reader to become aware of nature's role in human life. The author, describing insects' behaviour, approaches philosophical way of thinking about human existence. While observing a wedding dance of the Queens, William draws the conclusion that it is a great example of Charles Darwin's theory; males struggle to possess the Queens. This is "the remorseless random purposefulness of Dame Nature, of Natural Selection" (Byatt, 1992, p. 102). As a representative of an academic world, William sees great power in nature claiming that God was created by people themselves and that it is nature that rules lives.

Another part of Angels and Insects entitled "The Conjugal Angel", uses mainly metafictional references. The whole part presents Byatt's vision of the figures of Arthur H. Hallam and Alfred Tennyson. The story presents Emily Jesse and a group of her friends who meet during séances to talk to the ghosts of the dead. During the whole of the story Emily expresses her longing for her dead fiancé Arthur H. Hallam and analyses poems by her brother Alfred Tennyson. The first group of references is related to an imitation of the nineteenth-century world. It can be categorized as the 'text versus reality' relations. Mrs. Papagay who organises the séances, perceives the contacts with ghosts as quite natural; "The Church Fathers too had seen them and some had seen unquiet spirits. Hamlet's father had walked (...) there had always been, Mrs. Papagay was quite sure, odd little local apparitions" (Byatt, 1992, p. 170). Understanding the idea of séances in this way, Mrs. Papagay makes them a popular free time activity among her friends. The narrator of the story, using Mrs. Papagay's thoughts, presents to the reader the figures of The Conjugal Angel. He mentions not only Emily Jesse, but also her father, fiancé and brother. Presenting the two young men to the reader, the narrator says:

\footnotetext{
${ }^{2}$ The appearance of the title page, as well as further pages containing the titles of particular chapters, exactly imitates real books and it has a visual effect. This kind of quotation is a typical postmodern technique.
} 
Alfred Tennyson had written In Memoriam which had made Arthur Hallam, A. H. H., an object of national mourning nearly twenty years after his death, and had later caused the nation somehow to confound his young promise with the much mourned Prince Albert, let alone the legendary King Arthur. (Byatt, 1992, p. 175)

There is no doubt that poetry immortalizes people and is a powerful tool in creating national culture and identity. The reader also becomes familiar with the figure of Arthur H. Hallam from his letters, which constitute another intertextual reference imitating reality. Byatt includes in her work his correspondence with Emily, in which he appears to be a caring and loving man (Byatt, 1992, p. 230231). The letters become one of the ways of narration and allow the reader to become familiar with the story on the basis of a primary source. Emily herself lives constantly recalling the moments spent with Arthur. She remembers him compare her to the Fair Persian from Alfred Tennyson's work Recollections of the Arabian Nights (Byatt, 1992, p. 224). In another letter, Hallam discusses with his fiancée his own work Theodicaea: "I do not think women ought to trouble themselves much with theology: we who are more liable to the subtle objections of the Understanding, have more need to handle the weapons that lay them prostrate" (Byatt, 1992, p. 217).

Hallam's point of view reflects the Victorian idea of female's place in society: she should not be interested in literature and philosophy, since she is expected to fulfil other domestic duties. The above quotation reflects a typical nineteenth-century view on gender roles. This shows another intertextual dependence in "The Conjugal Angel", which is 'text versus text'. The story contains works by both Hallam and Tennyson.

"In Memoriam" is the most frequently quoted literary work in the book by Byatt. The protagonists perceive the poem as "the greatest poem of their time" (Byatt, 1992, p. 233). The reader experiences its unusual analysis; it is Emily who analyses certain passages of "In Memoriam". She recognized herself in the sixth lyric, in which Arthur is expected to return to a young girl, but never manages to do so (Byatt, 1992, p. 233). The analysis is carried out from the girl's point of view; she is the central character in the poem. Emily also notices that Alfred Tennyson concentrated some parts of his work on his grief after losing a friend and there is just a brief mention of her sadness:

Alfred had taken Arthur and bound him to himself, blood to blood and bone to bone, leaving no room for her. It was true that late in the poem, reference was made to her love and her loss, but that too, was painful, most painful. Alfred had allowed his fantasy to imagine Arthur's future, Arthur's children, Alfred's nephews and nieces, mixing their blood. (Byatt, 1992, p. 234)

It seems that Emily suffers from an unfulfilled promise to start a family with Arthur. She also feels embarrassed because of her marriage with Mr. Jesse and having two sons with him. She cannot get rid of the feeling that her and Arthur's unborn children mentioned in the poem are more cherished by the nation than her real ones. She feels guilty for getting married after Arthur's death and thinks that people blame her for that (Byatt, 1992, p. 235). This is another comment on the female roles in the Victorian world. Emily subconsciously knows that she did not fulfil the duty that society expected from her. She also notices that in his poem Alfred Tennyson describes his sister Cecilia's wedding, while her wedding with Mr. Jesse was completely omitted as inconvenient for public opinion (Byatt, 1992, p. 235-236).

Byatt also quotes those passages of "In Memoriam" that refer to the question of the afterlife. Emily liked the particular passage describing the dangers of rising from the dead. Their coming could interrupt the present life: wives have new husbands, lands have new owners. Although Emily missed Arthur very much, she had never succeeded in talking to him during the séances (Byatt, 1992, p. 176177). Both Emily and Alfred believed in the afterlife and hoped that the human soul lives on after death: "If there were no afterlife, he shouted at his friends, if it were proved to him that was so, he would jump into the Seine or the Thames, he would put his head in the oven, he would take poison or fire a pistol at his own temple" (Byatt, 1992, p. 184). 
The analysis of the poem by Emily, as well as organisation of the séances by Mrs. Papagay, are attempts at understanding the idea of life and death. On the one hand, the protagonists try to grasp the contact with dead members of their families, but on the other hand, they are aware of the fact that it is impossible. Their attempt to link the world of the living with the dead seems to be destroyed by the metaphorical appearance of a raven during one of the séances. The participants agree that the bird resembles the one from the poem by Edgar Allan Poe "The Raven". The famous expression nevermore shows for the protagonists their obsessive grief after losing a beloved person and lack of faith that he or she will ever rise from the dead (Byatt, 1992, p. 209).

\section{Conclusion}

Byatt's entire work exploits various types of narrative techniques and intertextual references, diverging in this way from the typical, chronological narration popular in Victorian times. They are used to present different worlds: of people, animals and the dead, and to show the relationships between them. Using letters, poems and stories in different combinations can also be perceived as literary criticism towards nineteenth-century writing. Byatt uses other texts which enhance the author's primary text. According to Michał Głowiński, these different quotations from other works do not make up an example of a polyphonic work, but, on the contrary, prove the text to be monodic $(2000$, p. 23$)$. The reader is distanced from the basic level of the story only to go back to it after some time (Bartoszyński, 1991, p. 12). Byatt's work exploits history as well; the reader becomes more familiar with the figures of famous English artists and thinkers. The historic nature of the work as well as examples of intertextuality are some of the elements that indicate its metafictional character (Hutcheon, 1997, p. 389).

\section{References}

Bartoszyński, K. (1991). Powieść w świecie literackości. Warszawa: Instytut Badań Literackich PAN. Byatt, A. S. (1992). Angels and Insects. London: Chatto and Windus.

Genette, G. (2014). Palimpsesty. Literatura drugiego stopnia. Translated by T. Stróżyński \& A. Milecki. Gdańsk: Wydawnictwo słowo/obraz terytoria.

Głowiński, M. (2000). Intertekstualność, groteska, parabola. Prace wybrane, volume V. Kraków: Towarzystwo Autorów i Wydawców Prac Naukowych UNIVERSITAS.

Hejmej, A. (2012). Muzyka w literaturze. Kraków: Towarzystwo Autorów i Wydawców Prac Naukowych UNIVERSITAS.

Hutcheon, L. (1997). Historiograficzna metapowieść: parodia i intertekstualność historii. Nycz, R. (Ed.), Postmodernizm, antologia przekładów. Kraków: Wydawnictwo Baran i Suszczyński.

Markiewicz, H. (1989). Literaturoznawstwo i jego sq̨siedztwa. Warszawa: Wydawnictwo PWN.

Nycz, R. (1995). Tekstowy świat. Poststrukturalizm a wiedza o literaturze. Warszawa: Wydawnictwo Instytutu Badań Literackich PAN.

\section{Contact}

dr Agata Buda

Kazimierz Pułaski University of Technology and Humanities in Radom, Poland

31 Chrobrego Str.

26-600 Radom, Poland

a.buda@uthrad.pl 